\title{
1. Neoliberalism and globalization: the puzzle of Chile and Taiwan
}

The controversial terms, "neoliberalism" and "globalization", have become increasingly utilized, both as academic concepts and policy packages, over the last four decades. To some academics and policy-makers, they represent a panacea that can unlock stagnant economies and bring greater prosperity throughout the world. In contrast, these advocates have been sharply challenged from two distinct perspectives. First, neoliberalism and globalization have been condemned as smokescreens for promoting the vested interests of corporations and the wealthy at the expense of the rest of society. Second, they have been criticized for ignoring the actual economic dynamics that operate at both the national and international levels.

A good example of the potency of neoliberalism and globalization comes from Chile, the nation that arguably introduced neoliberalism in the mid-1970s after the bloody military coup led by Augusto Pinochet in 1973. The regime negotiated with extreme laissez-faire economists who had been trained at the University of Chicago to redirect the nation's economic policy, as well as turning to Milton Friedman and his University of Chicago colleagues as advisors. The "Chicago Boys" opened the economy to global markets and implemented a wide range of anti-statist policies (Fischer, 2009; Klein, 2007; O’Brien, 1981; Valdes, 1995). One would expect descriptions of their policies as neoliberal and pro-globalization to be familiar only to academics and some policy-makers. Yet, interviews in Chile found that these terms were widely understood in the early twenty-first century by social advocates, community leaders, and employees who could discuss their consequences with some sophistication (Clark, 2013).

During the 1970s and 1980s, government programs to promote economic development and social equity were severely discredited by the combination of growing economic problems in many developing nations that had pursued industrialization through import-substitution policies, the economic stagnation in many European social welfare states, and finally the collapse of Soviet Communism (Clark and Roy, 1997; Gilpin, 1987). This resulted in growing advocacy of subordinating government to the free flows of the marketplace. In particular, the emerging school of neoliberalism believed that countries should end restrictions on private business, 
decrease government spending and debt, and open their markets to the international economy to take advantage of the growing ease of trade and finance around the world that has been termed "globalization". By the 1990s, neoliberalism and globalization were combined to form an emerging orthodoxy in international policy circles that was termed the "Washington consensus" (Balassa, 1981; Friedman, 2001; Gilder, 1984; Linder, 1986; von Mises, 1983). Within academia, this commitment to free markets dominated economics, but was sharply challenged by a variety of scholars in other disciplines who argued that neoliberalism and globalization were simply shibboleths used by the rich and powerful to advance their vested interests, and/or that other models of development had been quite successful. Furthermore, popular protests have erupted against the policies and institutions of neoliberalism in both the developed and developing world (Harvey, 2005; Mirowski, 2013; Steger and Roy, 2010).

From one perspective, the political economies of Chile and Taiwan might appear to be poster children for neoliberalism and globalization. Both took aggressive policy actions (Taiwan in the 1960s and Chile in the 1970s) to create market-driven economies that were well integrated into the capitalist global economy. Subsequently, these two countries were cited as "economic miracles" that opened their markets, resulting in rapid economic growth and development. A closer examination of the two nations, however, highlights very significant differences between them. Chile created a wide range of industries serving the domestic market early under importsubstitution in the 1940s and 1950s, but its market reforms did little to promote industry. In contrast, Taiwan has been much more successful in upgrading its economy, achieving and sustaining rapid growth, reducing inequality, and building a prosperous society with a capacity for moving into increasingly advanced economic sectors (Clark and Tan, 2012; Clark, 2013). This creates something of a puzzle for both the advocates and critics of neoliberalism and globalization since both sides agree, at least implicitly, that neoliberal policies set off a series of effects, albeit they disagree adamantly on what these effects have been.

The major argument in this book is that Taiwan's export-led development strategy succeeded precisely because it discarded the ideology of neoliberalism and unfettered laissez-faire. In particular, rapid industrialization in Taiwan could only occur because the government promoted a series of fundamental economic transformations during the post World War II era. In addition, radical land reform and mass education reduced inequality and created the human capital necessary for an industrial workforce and highly entrepreneurial business class. In sharp contrast, neoliberalism in Chile worked primarily to reinforce the economic position of the traditional economic elites; indeed, it actually undercut the economic position 
of manufacturing. Therefore, it did not spur the restructuring of the economy and society (Clark and Tan, 2012; Clark, 2013).

We apply institutionalist theory to explain the major differences between Chile and Taiwan. According to this theory, a nation's political and economic institutions shape its socioeconomic outcomes in ways which can vary considerably in their success, and which inevitably favor some groups and are disadvantageous to others (March and Olsen, 1989; North, 1990). In particular, the power of landed elites and the military in Chile has remained strong, which has inhibited the country's ability to pursue industrial development and upgrading. In contrast, a more felicitous combination of factors in Taiwan has promoted rapid economic and social development due to, in the terms of Chan and Clark (1992), Flexibility, Foresight, and Fortuna. A comparison of Chile and Taiwan also indicates that neoliberalism and globalization are far from synonymous since Taiwan benefitted much more from globalization than did Chile, while having a government that had a fairly strong industrial policy.

\section{PLAN OF THE BOOK}

Chapter 2 on "Neoliberalism and the paradoxes in economic theory" provides the theoretical background for our comparison of Chile and Taiwan. It begins with an overview of neoliberalism and globalization which introduces these two concepts and discusses the controversy over them in academic and policy debates. The second part of the chapter presents a series of paradoxes in basic economic theory and shows that these paradoxes present daunting challenges to both the advocates and critics of neoliberalism and globalization. Third, the normal pattern or sequence of economic development is examined in light of the paradoxes that we raise. Finally, we introduce institutionalist theory as a means for transcending these paradoxes and explaining the trajectories of the political economies of Chile and Taiwan.

We begin our comparative analysis in Chapter 3 on "The stereotype of the economic miracles: free markets." The economic miracles of these two countries are often cited as showcases for the success of neoliberalism and globalization. Perhaps the most important characteristic of these two countries in this regard is that they opened their markets to foreign trade and foreign investment, as neoliberals would prescribe allowing a nation to take advantage of globalization. This chapter compares the periods of international market-opening in Chile (1975-1980) and Taiwan (1964-1972). We briefly examine the background factors to the marketization reforms, with special emphasis on the import-substitution that had 
previously been in effect and on the political calculations behind these dramatic changes in course. The reforms themselves are then described in some detail. Finally, the chapter charts the economic results that were soon to be called "miracles."

Chapter 4 develops "An overall model of development in Taiwan;" and Chapter 5 presents a similar model for Chile. In each chapter, we start with a background discussion of how both countries experienced a preliminary industrialization that faltered for different reasons, creating economies that were primarily dependent upon primary products for their exports. The bulk of each chapter is then devoted to tracing the complex web of interacting effects among government policies, economic change, and social outcomes. In the economic realm, we chart how specific policies affected the economy; what the government did to promote human capital; and how economic change at one stage created possibilities for subsequent new policies and economic upgrading. In terms of social outcomes, we examine how economic change affected social conditions and the lives of the people; how the government responded to social change or the lack thereof; and the role of human capital in economic development.

Chapter 6 on "Neoliberalism and the economic miracles in Chile and Taiwan" then applies the data and analyses from Chapters 3 to 5 to evaluate neoliberalism's ability to promote economic and social development. The first section compares these two political economies. Despite their similar strategies of opening their markets to the global economy and pursuing export-led growth, the differences between Chile and Taiwan are profound and highly consequential. Five differences in particular are quite dramatic. First, Chile implemented a full package of explicitly neoliberal reforms, while Taiwan did not. Second, Taiwan engaged in substantial economic upgrading throughout the second half of the twentieth century, while the opening of the Chilean economy did not affect that nation's manufacturing sector very much at first but then led to its marked decline. Third, opening Taiwan's economy to globalization was followed by "growth with equity" as poverty and income inequality dropped substantially, while the market reforms of Pinochet and his Chicago Boys led to a massive jump in poverty and inequality. Fourth, in contrast to Chile's neoliberalism which extended into the post-Pinochet period, Taiwan's government often actively promoted the country's movement from one type of economic structure to another. Finally, Taiwan enacted a massive land reform program in the early 1950 , while Chile has generally protected the interests of its landed elites. The second section, "An institutional model of the divergence between Chile and Taiwan", summarizes the major economic, political, and social institutions in each nation and analyzes how these two distinct institutional structures have shaped economic and social 
outcomes in each country. Finally, a section, "Implications for globalization and neoliberalism", discusses how the paradoxes in economic theory discussed in Chapter 2 are reflected in the political economies of Chile and Taiwan, and what this implies about the effectiveness of neoliberalism. In particular, we conclude that if a country tries to take advantage of globalization to promote economic progress, it would be poorly served by adopting neoliberal policies. 